Journal of Telenursing (JOTING)

Volume 2, Nomor 1, Juni 2020

e-ISSN: 2684-8988

p-ISSN: 2684-8996

DOI: https://doi.org/10.31539/joting.v2i1.859

\title{
PENURUNAN TEKANAN DARAH PADA LANSIA DENGAN SENAM ERGONOMIS
}

\author{
Fatsiwi Nunik Andari ${ }^{1}$, Deoni Vioneery ${ }^{2}$, Panzilion $^{3}$, Nurhayati $^{4}$, Padila $^{5}$ \\ Universitas Muhammadiyah Bengkulu 1,3,4,5 \\ Sekolah Tinggi Ilmu Kesehatan Kusuma Surakarta ${ }^{2}$ \\ fatsiwiandari@umb.ac.id ${ }^{1}$
}

\begin{abstract}
ABSTRAK
Penelitian ini bertujuan untuk mengetahui bagaimana pengaruh senam ergonomis terhadap penurunan tekanan darah pada lansia dengan hipertensi di Balai Penyantunan dan Perawatan Lanjut Usia. Metode yang digunakan dalam penelitian adalah metode quasy experiment dengan rancangan one group pre and post test design. Hasil analisis menunjukkan bahwa terdapat perbedaan rata-rata tekanan darah sistolik sebelum dan setelah dilakukan senam ergonomis yaitu 14,00 dan tekanan darah diastolik sebelum dan setelah dilakukan senam ergonomis yaitu 8,00. Hasil uji bivariat didapatkan p-value 0,00. Simpulan, terdapat pengaruh intervensi senam ergonomis terhadap penurunan tekanan darah lansia dengan hipertensi di Balai Penyantunan dan Perawatan Lanjut Usia.
\end{abstract}

Kata Kunci : Hipertensi, Lansia, Senam Ergonomis

\section{ABSTRACT}

This study aims to determine the influence of ergonomic exercise on reducing blood pressure in the elderly with hypertension at the Center for Sponsorship and Elderly Care. The method used in this research is the quasi-experiment method with one group pre and post-test design. The results of the analysis showed that there were differences in the average systolic blood pressure before and after the ergonomic exercise was 14.00, and the diastolic blood pressure before and after the ergonomic practice was 8.00. Bivariate test results obtained a p-value of 0.00. In conclusion, there is the influence of ergonomic exercise intervention on the reduction of blood pressure in the elderly with hypertension at the Center for Support and Care for the Elderly.

Keywords: Hypertension, Elderly, Ergonomic Gymnastics

\section{PENDAHULUAN}

Hipertensi adalah suatu keadaan ketika tekanan darah di pembuluh darah meningkat secara kronis yang didasarkan pada dua fase dalam setiap denyut jantung yaitu fase sistolik $140 \mathrm{mmHg}$ yang menunjukkan fase darah yang sedang dipompa oleh jantung dan fase diastolik $90 \mathrm{mmHg}$ yang menunjukkan fase darah yang kembali ke jantung. Keadaan ini dapat terjadi karena jantung bekerja lebih keras memompa darah untuk memenuhi kebutuhan oksigen dan nutrisi tubuh, sehingga bila kondisi ini dibiarkan terus terjadi dapat mengganggu fungsi organ-organ lain terutama organ-organ vital seperti jantung dan ginjal (Riskesdas, 2013). Hipertensi didefinisikan secara 
singkat sebagai tekanan darah persisten, dimana tekanan darah sistoliknya di atas 140 $\mathrm{mmHg}$ dan tekanan darah diastoliknya di atas $90 \mathrm{mmHg}$ (Padila, 2013).

Hipertensi atau tekanan darah tinggi telah menjadi penyakit tidak menular nomor satu yang menjadi perhatian dibanyak negara di dunia, termasuk di Indonesia. Hipertensi yang dikenal juga sebagai the silent killer merupakan salah satu kontributor utama terjadinya penyakit jantung, gagal ginjal, kematian prematur dan stroke yang bersama-sama menyebabkan peningkatan angka kematian dan kecacatan. Secara umum penderita hipertensi tidak menyadari bahwa mereka mengalami hipertensi dan bagi mereka yang telah didiagnosis pasti hipertensi mungkin tidak memiliki akses terhadap pengobatan dan tidak dapat mengontrol penyakit tersebut secara jangka panjang, sehingga penyakit hipertensi semakin bertambah jumlah penderitanya. Sekitar 9,4 juta kematian akibat penyakit kardiovaskuler terjadi setiap tahunnya yang disebabkan oleh hipertensi (WHO, 2012).

Pengendalian hipertensi dalam upaya mencegah terjadinya komplikasi akibat hipertensi belum menunjukkan hasil yang memuaskan. Rata-rata pengendalian hipertensi baru berhasil menurunkan prevalensi hingga $8 \%$ dari jumlah keseluruhan. Berdasarkan data $\mathrm{WHO}$ dari $50 \%$ penderita hipertensi yang diketahui, $25 \%$ yang mendapat pengobatan dan hanya $12,5 \%$ yang diobati dengan baik. Hasil Riset Kesehatan Dasar (Riskesdas) Kementerian Kesehatan Republik Indonesia (2013) menunjukkan bahwa prevalensi hipertensi di Indonesia pada golongan usia $\geq 18$ yang pernah didiagnosis tenaga kesehatan sebesar 9,4\%, dan yang sedang minum obat hipertensi sendiri sebesar 9,5\% (Padila, 2013). Hal ini berarti bahwa sekitar 0,1\% penduduk Indonesia minum obat sendiri meskipun tidak pernah didiagnosis hipertensi oleh tenaga kesehatan. Hasil Riskesdas (2013) juga menunjukkan bahwa cakupan tenaga kesehatan terhadap kasus hipertensi di masyarakat masih tergolong rendah, yaitu $36,8 \%$ dan sebagian besar yaitu $63,2 \%$ kasus hipertensi di masyarakat Indonesia tidak terdiagnosis.

Berdasarkan data yang diperoleh dari Balai Pelayanan dan Penyantunan Lanjut Usia (BPPLU) Provinsi Bengkulu pada Januari 2016, dari 63 orang lansia sebagian besar lansia tersebut (40 orang) mengalami hipertensi. Lansia adalah usia yang rentan mengalami hipertensi. Karena bertambahnya usia, maka tekanan darah juga akan meningkat. Hal ini dikarenakan setelah usia 45 tahun, dinding arteri akan mengalami penebalan oleh karena adanya penumpukan zat kolagen pada lapisan otot, sehingga pembuluh darah akan berangsur-angsur menyempit dan menjadi kaku. Tekanan darah sistolik meningkat karena kelenturan pembuluh darah besar yang berkurang pada penambahan usia (Pradetiawan, 2014).

Dengan tingginya angka kejadian hipertensi yang ada di Indonesia namun upaya untuk mengendalikan hipertensi tersebut masih kurang, perlu adanya berbagai macam upaya yang bisa dilakukan untuk mengendalikan angka kejadian hipertensi yang tinggi tersebut sehingga dapat menekan angka hipertensi (Andri et al., 2018; Sartika et al., 2018).

Penanganan hipertensi dapat dilakukan dengan berbagai cara, baik secara farmakologis, non farmakologis atau bisa juga kombinasi dari kedua-duanya (Padila, 2012). Penanganan hipertensi secara farmakologis yaitu dengan menggunakan obatobatan anti hipertensi yang didapatkan penderita hipertensi dari pelayanan kesehatan. Penanganan hipertensi secara nonfarmakologis adalah dengan melakukan modifikasi terhadap gaya hidup, seperti mengurangi berat badan yang berlebih, mengurangi asupan natrium dalam makanan yang dikonsumsi, tidak merokok dan mengkonsumsi alkohol, 
mengurangi konsumsi makanan yang mengandung lemak jenuh dan kolesterol, meningkatkan aktifitas fisik atau olahraga serta mengolah stress dengan baik atau melakukan manajemen stress. Selain untuk penatalaksanaan hipertensi, modifikasi gaya hidup juga dapat digunakan sebagai upaya pencegahan terjadinya hipertensi (Sari, 2017). Salah satu aktivitas fisik atau kegiatan olahraga pada terapi non farmakologis yang bisa dilakukan adalah dengan senam ergonomis (Sagiran, 2012).

Senam ergonomik adalah istilah yang sering digunakan dalam teknik pengamatan waktu dan gerakan serta produktivitas kerja (time and motion study, work measurement and productivity). Teknik ini bertujuan untuk mendapatkan suatu cara kerja dengan waktu yang optimal dan meminimalkan kelelahan (fatique), sehingga diperoleh tingkat produktivitas yang tinggi dan manusiawi (Wratsongko, 2015). Senam ergonomis merupakan salah satu metode praktis dan efektif dalam pemeliharaan kesehatan tubuh seseorang. Gerakan dalam senam ergonomis adalah serangkaian gerakan yang mirip dengan gerakan shalat karena sesungguhnya gerakan dalam senam ergonomis diilhami dari gerakan shalat yang sudah dilakukan oleh umat muslim sejak dulu hingga sekarang. Gerakan senam ergonomis ini sesuai dengan susunan dan fisiologi tubuh manusia. Gerakan senam ergonomis terdiri dari satu (1) gerakan pembuka yaitu berdiri sempurna dan lima (5) gerakan fundamental yaitu lapang dada, tunduk syukur, duduk perkasa, duduk pembakaran, dan berbaring pasrah (Sagiran, 2012; Andri et al., 2019).

Lansia dengan hipertensi yang berada di Balai Penyantunan dan Perawatan Lanjut Usia (BPPLU) Provinsi Bengkulu ini belum pernah mendapatkan intervensi kegiatan berupa senam yang secara khusus ditujukan untuk menurunkan tekanan darahnya. Selama ini semua lansia, baik yang mengalami hipertensi atau pun tidak mendapatkan kegiatan senam biasa atau senam lansia saja. Jadi senam ergonomis ini merupakan kegiatan senam baru bagi lansia di BPPLU, khususnya bagi lansia dengan hipertensi. Peneliti berasumsi bahwa suatu kegiatan baru yang dialami oleh seseorang, dalam hal ini adalah lansia, maka akan memberikan motivasi bagi lansia tersebut untuk mengikuti kegiatan ini dengan baik.

\section{METODE PENELITIAN}

Penelitian ini adalah penelitian kuantitatif dengan menggunakan metode quasi eksperiment (eksperimen semu) dengan rancangan one group pre and post test design. Penelitian ini dimulai dari pengurusan izin penelitian ke berbagai pihak terkait, selanjutnya informed consent pada responden. Proses selanjutnya adalah pengukuran tekanan darah responden (lansia dengan hipertensi) sebelum dilakukan intervensi senam ergonomis. Intervensi senam ergonomis diberikan dengan frekuensi $2 x$ dalam seminggu selama 2 minggu, sehingga total intervensi senam ergonomis yang dilakukan oleh lansia dengan hipertensi adalah sebanyak 4 kali. Setelah diberikan intervensi, peneliti mengukur kembali tekanan darah responden.

Jumlah sampel dalam penelitian ini sebanyak 30 orang responden lansia dengan hipertensi. Sampel yang diambil menggunakan tehnik purposive sampling. Instrument dalam penelitian ini adalah spignomanometer (tensimeter), buku catatan dan alat tulis, serta modul senam ergonomis untuk membantu responden dalam memahami gerakangerakan dalam intervensi senam ergonomis yang diberikan.

Analisis data yang digunakan adalah analisis univariat dan bivariat. Analisis univariat dilakukan untuk mengetahui karakteristik gambaran status tekanan darah responden sebelum dan setelah dilakukan senam ergonomis, yang disajikan dalam bentuk tabel distribusi frekuensi. Analisis bivariat dalam penelitian ini dilakukan untuk 
mengetahui pengaruh intervensi senam ergonomis terhadap penurunan tekanan darah lansia yang mengalami hipertensi. Sebelum data dianalisis dilakukan uji normalitas terlebih dahulu untuk mengetahui apakah data hasil penelitian yang didapat berdistribusi normal atau tidak. Hasil uji normalitas yang dilakukan didapatkan data tidak berdistibusi normal sehingga uji analisis data dalam penelitian ini menggunakan uji wilcoxon.

\section{HASIL PENELITIAN Analisis Univariat}

Tabel. 1

Distribusi Frekuensi Tekanan Darah Sistolik dan Diastolik Sebelum Dilakukan Senam Ergonomis

\begin{tabular}{ccccc}
\hline Kategori & Frekuensi $(\mathrm{N})$ & Mean & Minimal & Maximal \\
\hline TD sistolik & 30 & 160,00 & 140 & 190 \\
TD diastolik & 30 & 95,00 & 90 & 110 \\
\hline
\end{tabular}

Berdasarkan tabel 1 dapat diketahui bahwa rata-rata tekanan darah sistolik sebelum dilakukan senam ergonomis adalah $160,00 \mathrm{mmHg}$, sementara untuk rata-rata tekanan darah diastoliknya adalah $95,00 \mathrm{mmHg}$.

Tabel. 2

Distribusi Frekuensi Tekanan Darah Sistolik dan Diastolik Setelah Dilakukan Senam Ergonomis

\begin{tabular}{ccccc}
\hline Kategori & Frekuensi $(\mathrm{N})$ & Mean & Minimal & Maximal \\
\hline TD sistolik & 30 & 145,33 & 130 & 160 \\
TD diastolic & 30 & 89,67 & 80 & 100 \\
\hline
\end{tabular}

Berdasarkan tabel 2 dapat diketahui bahwa rata-rata tekanan darah sistolik setelah dilakukan senam ergonomis adalah $145,33 \mathrm{mmHg}$. Untuk rata-rata tekanan darah diastoliknya 89,67. Hasil ini menunjukkan bahwa terdapat penurunan rata-rata tekanan darah pada lansia setelah dilakukan intervensi senam ergonomis secara rutin dengan frekuensi $2 \mathrm{x}$ dalam seminggu selama 2 minggu.

\section{Analisis Bivariat}

Tabel. 3

Perubahan Tekanan Darah Sistolik dan Diastolik Responden Sebelum dan Setelah Dilakukan Senam Ergonomis

\begin{tabular}{rlcccc}
\hline Kategori & Perlakuan & SD & Mean Rank & z-value & p-value \\
\hline TD Sistolik & Sebelum & $\begin{array}{c}11,447 \\
7,761\end{array}$ & \multirow{2}{*}{14,00} & $-4,651$ & \multirow{2}{*}{0,000} \\
& Setelah & 7,724 & \multirow{2}{*}{8,00} & $-3,771$ & \multirow{2}{*}{0,000} \\
\hline \multirow{2}{*}{ TD Diastolik } & Sebelum & 5,00 & & \\
& Setelah & 3,198 & & & \\
\hline
\end{tabular}

Berdasarkan tabel 3 dapat diketahui bahwa nilai $\mathrm{p}$ ( $p$-value) tekanan darah sistolik dan diastolik sebelum dan setelah dilakukan intervensi senam ergonomis adalah 0,000. Dengan demikian dapat disimpulkan bahwa terdapat pengaruh yang signifikan antara sebelum dan setelah dilakukan intervensi senam ergonomis terhadap tekanan darah sistolik dan diastolik lansia. 


\section{PEMBAHASAN}

\section{Hasil Pengukuran Tekanan Darah Responden Sebelum Diberikan Intervensi}

Berdasarkan tabel 1 dapat diketahui bahwa sebelum dilakukan intervensi senam ergonomis rata-rata tekanan darah sistolik adalah $160,00 \mathrm{mmHg}$ dan rata-rata tekanan darah diastoliknya adalah $95,00 \mathrm{mmHg}$.

Tekanan darah sistolik adalah tekanan yang dihasilkan oleh otot jantung saat mendorong darah dari ventrikel kiri ke aorta (tekanan pada saat kontraksi atau menguncupnya otot ventrikel jantung), sedangkan tekanan darah diastolik adalah tekanan pada dinding arteri dan pembuluh darah akibat mengendurnya atau rileksasi otot ventrikel jantung (tekanan pada saat otot atrium jantung kontraksi dan darah menuju ventrikel (Suri, 2017). Tekanan darah pada hasil penelitian ini dengan tekanan sistolik tertinggi adalah $190 \mathrm{mmHg}$ dan diastolik tertinggi adalah $110 \mathrm{mmHg}$ masuk dalam kategori hipertensi stage III atau hipertensi tahap III (American Heart Association, 2014). Bertambahnya beban kerja jantung ini dikarenakan tubuh membutuhkan suplai oksigen yang lebih besar. Adanya sumbatan di pembuluh darah perifer juga dapat mengurangi suplai darah ke jantung sehingga beban kerja jantung meningkat (Handriani, 2012).

Menurut Kartikasari (2012) dampak lain yang bisa timbul dari hipertensi adalah terjadinya komplikasi seperti pada organ otak, jantung, ginjal dan mata. Pada otak akan menyebabkan terjadinya penyakit stroke baik yang timbul karena perdarahan, tekanan intra kranial yang meninggi (yang sering disebut dengan stroke hemoragik), atau akibat embolus yang terlepas dari pembuluh darah non otak yang terpajan tekanan darah tinggi yang persisten (disebut dengan stroke non hemoragik). Pada organ jantung dapat menimbulkan komplikasi gagal jantung kongestif, angina dan serangan jantung. Pada organ ginjal dapat terjadi kerusakan glomerulus yang dapat berlanjut menjadi hipoksia, gagal ginjal dan kematian ginjal. Pada organ mata dapat menyebabkan kerusakan pembuluh darah pada retina (vascular retina) yang terjadi karena adanya penyempitan atau penyumbatan pembuluh arteri di mata dan dapat terjadi pula kerusakan pada saraf mata.

Tekanan darah yang tinggi pada lansia di BPPLU ini sebagian besar disebabkan faktor keturunan dan faktor konsumsi makanan yang tinggi garam, kebiasaan merokok serta jarangnya mereka melakukan olahraga di masa muda dulu. Padahal hipertensi dapat dikendalikan oleh penderitanya dengan pola hidup yang sehat, seperti mengurangi atau membatasi konsumsi garam dan makanan tinggi lemak, tidak merokok, tidak mengkonsumsi alkohol, tidak mengkonsumsi makanan cepat saji, serta tidak malas berolahraga (Syamsudin, 2011).

Berdasarkan keterangan dari pengelola panti dan beberapa responden, mereka (lansia) yang menderita hipertensi di BPPLU tidak rutin mengikuti kegiatan senam yang diadakan oleh pihak panti. Lansia lebih sering memilih untuk tetap tinggal di kamar wismanya. Di dalam kamar atau wismanya lansia jarang melakukan latihan olahraga (exercise) yang terencana, terstruktur, berulang, dan bertujuan untuk memelihara kebugaran fisik. Hasil penelitian Herdati \& Ahmad (2017) menyatakan bahwa aktivitas fisik berpengaruh terhadap kejadian hipertensi. Selain itu factor risiko lainnya yaitu usia, dalam hal ini adalah lansia dengan usia $\geq 60$ tahun. Olahraga yang dilakukan secara teratur dapat menyerap atau menghilangkan endapan kolestrol pada pembuluh darah nadi. Olahraga yang dimaksud adalah latihan menggerakan semua nadi dan otot tubuh seperti gerak jalan, berenang, naik sepeda, aerobik. Olahraga lain yang dapat dilakukan secara rutin adalah senam ergonomis yang mudah untuk dilakukan oleh 
siapapun, dimanapun dan kapanpun, bisa dilakukan berkelompok maupun per individu serta dapat disesuaikan dengan kemampuan individu tersebut (Sagiran, 2012).

\section{Hasil Pengukuran Tekanan Darah Responden Setelah Diberikan Intervensi}

Berdasarkan tabel 2 dapat diketahui bahwa setelah dilakukan intervensi senam ergonomis rata-rata tekanan darah sistolik adalah $145,33 \mathrm{mmHg}$ dan rata-rata tekanan darah diastoliknya 89,67 mmHg. Hasil ini menunjukkan bahwa terdapat penurunan ratarata tekanan darah pada lansia setelah dilakukan intervensi senam ergonomis.

Senam ergonomis yang dilakukan secara rutin dengan frekuensi $2 \mathrm{x}$ dalam seminggu selama 2 minggu ini memberikan kenyamanan pada responden. Gerakan senam ergonomis yang diilhami dari gerakan sholat ini terdiri dari gerakan lapang dada, tunduk syukur, duduk perkasa, duduk pembakaran, dan berbaring pasrah, serta gerakan penutup dapat dilakukan sesuai dengan kemampuan lansia. Sagiran (2012) menjelaskan bahwa gerakan senam ergonomis yang meliputi gerakan pada bagian tangan, kaki, disertai dengan pernapasan yang diatur dengan rileks mampu menghimpun udara sebanyak mungkin dalam paru-paru sehingga paru-paru dapat menyerap oksigen sebanyak mungkin yang bermanfaat untuk melakukan aktivitas. Gerakan duduk perkasa seperti sujud dalam salah satu gerakan pada senam ergonomis akan membuat otot dada dan sela iga menjadi kuat sehingga rongga dada mejadi lebih besar dan paru-paru akan berkembang dengan baik dan dapat menghisap oksigen lebih banyak. Gerakan seperti sujud ini juga dapat menambah aliran darah ke bagian atas tubuh terutama bagian mata, kepala, telinga, hidung, serta paru-paru sehingga memungkinkan toksin-toksin dibersihkan oleh darah dan dapat mengontrol tekanan darah tinggi.

Hasil penelitian ini sejalan dengan hasil penelitian Rizkiyatiningsih et al., (2014) tentang pengaruh senam ergonomis terhadap penurunan tekanan darah dengan hipertensi derajat I pada lansia di Kecamatan Gatak Sukoharjo, dengan hasil yaitu terdapat penurunan rata-rata tekanan darah pada kelompok lansia yang mengikuti senam ergonomik, dimana rata-rata tekanan darah sistolik $119.00 \mathrm{mmHg}$ dan rata-rata tekanan darah diastolik $80.00 \mathrm{mmHg}$. Penurunan tekanan darah ini terjadi setelah lansia mengikuti kegiatan senam ergonomik dengan frekuensi $3 \mathrm{x}$ selama 3hari berturut-turut dengan durasi waktu \pm 45-60 menit. Hal ini disebabkan karena aktifitas fisik dan olahraga yang teratur akan meningkatkan fungsi seluruh sistem tubuh seperti jantung dan paru , kebugaran otot dan tulang, pengaturan dan pemeliharaan berat badan serta kesejahteraan psikologis.

Hasil penelitian lainnya juga menyebutkan bahwa senam ergonomis efektif dalam menurunkan tekanan darah bagi lansia di Posyandu Lansia Ayah Bunda Wilayah Kerja Puskesmas Andalas Padang (Novia, 2015). Penelitian lain yang dilakukan oleh Priyanti (2016) juga menyebutkan bahwa senam ergonomis yang dilakukan baik secara individu atau sendiri-sendiri, maupun dilakukan secara berkelompok atau bersama-sama efektif dalam menurunkan tekanan darah pada lansia dengan hipertensi di Kelurahan Gisikdrono Semarang.

\section{Perbedaan Rata-Rata Tekanan Darah Lansia dengan Hipertensi di BPPLU dengan Senam Ergonomis}

Berdasarkan tabel 3 dapat diketahui bahwa terdapat pengaruh yang signifikan antara sebelum dan setelah dilakukan intervensi senam ergonomis terhadap penurunan tekanan darah sistolik dan diastolik lansia dengan hipertensi di BPPLU Provinsi Bengkulu. 
Adanya penurunan tekanan darah pada lansia yang mengalami hipertensi ini menurut pandangan peneliti dikarenakan lansia mengikuti kegiatan senam ergonomis secara rutin sesuai dengan waktu yang telah disepakati bersama sebelumnya. Wratsongko (2015) menyatakan bahwa untuk mendapatkan hasil yang memuaskan, akan lebih baik jika senam ini dilakukan secara berkelanjutan, sekurang -kurangnya 2-3 kali seminggu \pm 20 menit jika semua gerakan dilakukan sempurna. Gerakan-gerakan dalam senam ergonomis dapat mengaktifkan fungsi organ dan fungsi serabut saraf segmen di seluruh tubuh dengan cara membangkitkan bio listrik dalam tubuh dan sekaligus meningkatkan sirkulasi darah dan oksigen di dalam tubuh. Dengan rutinnya lansia mengikuti kegiatan senam ergonomis, maka bio listrik yang diaktifkan dalam tubuh dan sirkulasi darah serta oksogen dalam tubuh senantiasa terjaga dengan baik. Gerakan-gerakan dalam senam ergonomis juga disertai dengan adanya latihan pernapasan disetiap gerakannya sehingga tubuh dapat mengumpulkan udara dan asupan oksigen dalam jumlah banyak untuk dapat mengalir di seluruh tubuh (Sagiran, 2012).

Penanganan hipertensi dapat dilakukan dengan berbagai cara, baik secara farmakologis, non farmakologis atau bisa juga kombinasi dari kedua-duanya (Padila, 2012). Penanganan hipertensi secara farmakologis yaitu dengan menggunakan obatobatan anti hipertensi yang didapatkan penderita hipertensi dari pelayanan kesehatan.

Senam ergonomis merupakan salah satu metode praktis dan efektif dalam pemeliharaan kesehatan tubuh seseorang. Gerakan dalam senam ergonomis adalah serangkaian gerakan yang mirip dengan gerakan shalat karena sesungguhnya gerakan dalam senam ergonomis diilhami dari gerakan shalat yang sudah dilakukan oleh umat muslim sejak dulu hingga sekarang. Gerakan senam ergonomis ini sesuai dengan susunan dan fisiologi tubuh manusia. Gerakan senam ergonomis terdiri dari satu (1) gerakan pembuka yaitu berdiri sempurna dan lima (5) gerakan fundamental yaitu lapang dada, tunduk syukur, duduk perkasa, duduk pembakaran, dan berbaring pasrah (Sagiran, 2012; Andri et al, 2019).

Senam ergonomis yang digunakan sebagai terapi non farmakologi untuk menurunkan tekanan darah pada penderita hipertensi diperkuat oleh hasil penelitian dari Triwibowo (2015) yang menyatakan bahwa senam ergonomis memang berpengaruh pada tekanan darah penderita hipertensi. Hal ini dikarenakan dengan kondisi tubuh yang rileks, dan tidak mengalami stres membuat pembuluh darah akan berada pada kondisi vasodilatasi tanpa adanya tahanan. Kondisi ini dapat memaksimalkan suplai oksigen dan melancarkan sirkulasi darah ke seluruh tubuh. Lansia rentan untuk mengalami penyakit hipertensi. Hal ini dikarenakan semakin bertambahnya usia, arteri kehilangan elastisitas atau kelenturannya, sehingga volume darah yang mengalir menjadi sedikit dan kurang lancar. Pada lansia terjadi gangguan dalam pengaturan metabolisme zat kapur (kalsium) di dalam tubuhnya sehingga banyak zat kapur yang mengalir bersama darah. Jumlah kalsium yang banyak di dalam darah (hypercalcemia) mengakibatkan darah menjadi lebih padat dan kental, sehingga aliran darah di tubuh menjadi tidak lancer, dan akhirnya menyebabkan tekanan darah menjadi meningkat. Endapan kalsium di dinding pembuluh darah (arteriosclerosis) menyebabkan penyempitan pembuluh darah, akibatnya aliran darah menjadi terganggu, dimana volume darah yang mengalir sedikit dan kurang lancar. Kondisi ini dapat menimbulkan peningkatan tekanan darah (Dewi, 2014).

Gerakan-gerakan dalam senam ergonomis dapat merilekskan tubuh, melebarkan rongga dada dan membuat jantung bekerja secara normal. (Sagiran, 2012). Senam yang dilakukan secara rutin pada usia lanjut akan meningkatkan kebugaran fisik sehingga 
secara tidak langsung senam dapat meningkatkan fungsi jantung dan menurunkan tekanan darah serta mengurangi resiko penumpukan lemak pada dinding pembuluh darah sehingga akan menjaga elastisitas pembuluh darah. Senam juga dapat melatih otot jantung dalam berkontraksi sehingga kemampuan jantung dalam memompa terjaga dengan baik (Taufan, 2011). Menurut penelitian sebelumnya senam ergonomik dengan terapi musik dapat menurunkan tekanan darah pada lansia dengan hipertensi di Balai Perlindungan Sosial Tresna Werdah Ciparay Bandung dengan nilai rata-rata penurunan tekanan darah sistolik $10,42 \mathrm{mmHg}$ dan nilai rata-rata penurunan tekanan darah diastolik 5,41 mmHg (Nurazizah, 2014).

\section{SIMPULAN}

Berdasarkan hasil penelitian menunjukkan bahwa terjadi penurunan tekanan darah sistolik dan diastolik sebelum dan setelah diberikan intervensi senam ergonomis.

Berdasarkan uji analisis Wilcoxon diketahui bahwa terdapat pengaruh yang signifikan pemberian intervensi senam ergonomis terhadap penurunan tekanan darah lansia yang mengalami hipertensi di Balai Penyantunan dan Perawatan Lanjut Usia (BPPLU) Provinsi Bengkulu.

\section{SARAN \\ Bagi BPPLU}

Diharapkan pihak pengelola BPPLU Provinsi Bengkulu untuk dapat menerapkan kegiatan senam ergonomis ini dalam program kegiatan olahraga rutin lansia sebagai salah satu upaya menurunkan tekanan darah lansia yang mengalami hipertensi.

\section{Bagi Keilmuan}

Senam ergonomis terbukti dapat menurunkan tekanan darah penderita hipertensi sehingga hasil penelitian ini diharapkan dapat dijadikan sumber informasi khususnya bagi keperawatan untuk dapat diterapkan dalam pemberian tindakan asuhan keperawatan pada penderita hipertensi secara mandiri guna peningkatan asuhan keperawatan yang berkualitas yang dapat mengarah pada peningkatan kepuasaan pasien terhadap asuhan keperawatan yang diberikan.

\section{Bagi Penelitian Selanjutnya}

Hasil penelitian ini dapat dijadikan sebagai data awal dalam melakukan intevensi serupa dengan menambahkan variable lainnya seperti karakteristik responden, waktu pelaksanaan yang lebih lama, kombinasi intervensi atau membandingkan dengan intervensi lainnya.

\section{DAFTAR PUSTAKA}

American Heart Association, 2014. Heart Disease and Stroke Statistics. AHA Statistical p. 205. https://www.ahajournals.org/doi/10.1161/01.cir.0000441139.02102.80

Andri, J., Karmila, R., Padila, P., Harsismanto, J., \& Sartika, A. (2019). Pengaruh Terapi Aktivitas Senam Ergonomis terhadap Peningkatan Kemampuan Fungsional Lansia. Journal of Telenursing, 1(2), 304-313. https://doi.org/https://doi.org/10.31539/joting.v1i2.933

Andri, J., Waluyo, A., Jumaiyah, W., \& Nastashia, D. (2018). Efektivitas Isometric Handgrip Exercise dan Slow Deep Breathing Exercise terhadap Perubahan Tekanan Darah pada Penderita Hipertensi. Jurnal Keperawatan Silampari, 2(1), 
371-384. https://doi.org/10.31539/jks.v2i1.382

Dewi, S. (2014). Buku Ajar Keperawatan Gerontik. Yogyakarta: Deepublish Handriani, H. (2012). Pencegahan Hipertensi. Jakarta: Selemba Medika

Herdati, A. T., \& Ahmad, R. A. (2017). Aktivitas Fisik dan Kejadian Hipertensi pada Pekerja. Analisis Data 2013. https://media.neliti.com/media/publications/237978-none-8b366acc.pdf

Kartikasari, K. (2012). Faktor Risiko Hipertensi pada Masyarakat di Desa Kabongan Kidul Kabupaten Rembang. Jurnal Muda Medika. http://eprints.undip.ac.id/37291/

Novia, P. N. (2015). Pengaruh Senam Ergonomis terhadap Tekanan Darah Lansia Hipertensi di Posyandu Lansia Ayah Bunda Wilayah Kerja Puskesmas Andalas Padang. http://scholar.unand.ac.id/384/

Nurazizah, N. (2014). Pengaruh Senam Ergonomik dengan Terapi Musik terhadap Penurunan Tekanan Darah pada Lansia di Balai Perlindungan Sosial Tresna Werdha (BPSTW) Ciparay Bandung

Padila, P. (2012). Buku Ajar Keperawatan Medikal Bedah. Yogyakarta: Nuha Medika

Padila, P. (2013). Asuhan Keperawatan Penyakit Dalam. Yogyakarta: Nuha Medika

Padila, P. (2013). Buku Ajar Keperawatan Gerontik. Yogyakarta: Nuha Medika

Pradetiawan, P. (2014). Hubungan Usia dan Jenis Kelamin dengan Tekanan Darah Tinggi di Posyandu Lansia Desa Triyagan Mojolaban Sukoharjo. Universitas Muhammadiyah Surakarta, http://www. eprints.ums.ac.id/naskah publikasi

Priyanti, K. (2016). Pengaruh Senam Ergonomik Secara Kelompok dan Individu terhadap Penurunan Tekanan Darah pada Lansia dengan Hipertensi di Kelurahan Gisikdrono Semarang. https://scholar.google.co.id/scholar?hl=id\&as_sdt=0\%2C5

Riskesdas. (2013). Badan Penelitian dan Pengembangan Kesehatan, Departemen Kesehatan, Republik Indonesia. Jakarta

Rizkiyatiningsih, S., Maliya, A., \& Enawati, S. (2014). Pengaruh Senam Ergonomik terhadap Penurunan Tekanan Darah dengan Hipertensi Derajat I pada Lansia di Desa Wiromggan Kecamatan Gatak Sukoharjo. Skripsi. Universitas Muhammadiyah Surakarta. http://eprints.ums.ac.id/30725/14/naspub

Sagiran, S. (2012). Mukjizat Gerakan Shalat. Jakarta: Qultum Media

Sari, A., Lolita, L., \& Fauzia, F. (2017). Pengukuran Kualitas Hidup Pasien Hipertensi di Puskesmas Mergangsan Yogyakarta Menggunakan European Quality of Life 5 Dimensions (Eq5d) Questionnaire dan Visual Analog Scale (VAS). Jurnal Ilmiah Ibnu Sina, 1-12. http://jiis.akfarisfibjm.ac.id/index.php?journal=JIIS\&page=article

Sartika, A., Wardi, A., \& Sofiani, Y. (2018). Perbedaan Efektivitas Progressive Muscle Relaxation (PMR) dengan Slow Deep Breathing Exercise (SDBE) terhadap Tekanan Darah Penderita Hipertensi. Jurnal Keperawatan Silampari, 2(1), 356370. https://doi.org/https://doi.org/10.31539/jks.v2i1.380

Suri, A. (2017). Efektivitas Senam Tai Chi terhadap Penurunan Tekanan Darah pada Lanjut Usia dengan Riwayat Hipertensi di Puskesmas Junrejo Kota Batu. http://eprints.umm.ac.id/43202/

Syamsudin, S. (2011). Buku Ajar Farmakoterapi Kardiovaskular dan Renal. Jakarta: Salemba Medika

Taufan, N. (2011). Anatomi fisiologi Jantung dan Pembuluh Darah. Jakarta: EGC

Triwibiwo, T. (2015). Pengaruh Senam Ergonomik terhadap Tekanan Darah pada Penderita hipertensi di Desa Sumber Agung Kecamatan Jatirejo Kabupaten Mojokerto. http://garuda.ristekbrin.go.id/author/view/563099 
WHO. (2012). Global Hypertension Report. http://www.int/cardiovascular disease Wratsongko, M. (2015). Mukjijat Gerakan Shalat \& Rahasia 13 Unsur Manusia. Jakarta: Mizania 